\title{
Clover root weevil (Sitona lepidus) - a threat to the sustainability of white clover in New Zealand pastures?
}

\author{
B. WILLOUGHBY and P. ADDISON \\ AgResearch, Ruakura Research Centre, PB 3123, Hamilton
}

\begin{abstract}
Clover root weevil (Sitona lepidus) is established in Auckland, Waikato and Bay of Plenty provinces. A pasture survey in 1997 estimated that the rate of its spread at about $35 \mathrm{~km}$ annually. Adults feed on the foliage and larvae on roots and nodules of white clover. Pasture populations appear to be 10 times higher in New Zealand than in the UK. New Zealand's temperate climate and high clover content in pastures may offer a very favourable environment for S. lepidus, with serious implications for New Zealand's pastoral farming.
\end{abstract}

Keywords: clover root weevil, pasture pests, Sitona lepidus, Trifolium repens, white clover

\section{Introduction}

Sitona lepidus Gyllenhal (Coleoptera: Curculionidae) was first recognised in New Zealand pastures in the Waikato in March 1996 (Barratt et al. 1996). The species is of European origin and is common in pastures throughout Europe. It has been found in Finland as far north as $66-67^{\circ} \mathrm{N}$ (Markkula \& Koppa 1960). S. lepidus was first recorded in North America in 1873 and is now present from California through Canada to $50^{\circ} \mathrm{N}$ (Bright 1994). Unlike Sitona discoideus Gyllenhal, which was first reported in New Zealand in 1974 (Esson 1975), S. lepidus is not considered a migratory species. It generally travels by short flights or walking (Culick \& Weaver 1994). While not being an obligate feeder on white clover (Trifolium repens L.) S. lepidus strongly favours this legume (Murray \& Clements 1994). The adults feed on the foliage, causing characteristic ' $U$ ' shaped notches (Weich \& Clements 1992). The larvae feed on the roots and nodules and can cause severe damage to the plant to the detriment of its productivity and sustainability (Mowat \& Shakeel 1989; Clements \& Murray 1991).

Research to date since the identification of S. lepidus in New Zealand has focused on defining the problem. The area infested has been defined and the current rate of spread estimated. Damage assessment trials have been initiated both in the field and the laboratory and data are being collected on the population dynamics.
This paper summarises events following the first recognition of S. lepidus and presents some interim population data from a Waikato study site. Available information about the potential pest status of this insect is discussed within the context of the role of white clover as the key to profitability in New Zealand's pastoral industries.

\section{Arrival and spread}

Sitona lepidus was confirmed as present in New Zealand in March 1996 although it was retrospectively determined to have been present in 1995 (Barker et al. 1996). The identification arose when weevils of reproductive phenology inconsistent with that of $S$. discoideus were collected from pastures near Hamilton. The identity of the weevil was confirmed by New Zealand (G. Kuschel) and overseas entomologists (M.A. AlonsoZarazaga). MAF Regulatory Authority, which has the statutory responsibility for bio-security, was informed, and funded a survey conducted in April 1996 to assess the distribution of S. lepidus in the North Island (Barker et al. 1996). Two loci of establishment were defined encompassing an area in total of more than 200000 ha of improved farmland. A decision was made by MAF Regulatory Authority not to mount an eradication exercise as the area infested was too extensive for this to be practical. A pasture survey was conducted in April 1997 to assess the rate of spread of S. lepidus. The annual rate of spread was estimated at an average of 35 $\mathrm{km}$ with a range of 10 to $70 \mathrm{~km}$ (Willoughby \& Addison 1997). The absence of new loci of establishment suggested that $S$. lepidus is not a migratory species.

\section{Potential impact}

In Europe S. lepidus is mainly univoltine with adults over-wintering to feed and oviposit in spring (Murray 1991). The eggs are laid mostly on plant material but readily fall to hatch on the soil surface. The eggs require moisture and 230 day-degrees above $6.5^{\circ} \mathrm{C}$ to hatch (Mowat \& Clawson 1996). The larvae have five developmental instars. All stages feed preferentially on the roots of white clover with the first instar often found in the nodules (Murray \& Clements 1992). Larval infestations of approximately 1 per established clover 
plant are capable of causing significant damage, with 10 per plant in pot trials causing $100 \%$ plant mortality (Mowat \& Shakeel 1988). In the same study it was observed that the effects of larval feeding persisted long after the larvae had pupated. This was attributed to disease or vascular decay.

White clover in the UK makes a significant (greater than 5\%) contribution to the botanical composition in less than 20\% of swards (e.g., Forbes et al. 1980; Hopkins et al. 1985, 1988). In the UK nitrogenous fertilisers are relatively inexpensive and there is much less reliance on pasture-based stock feed than in New Zealand (P.J. Murray pers. comm.).

New Zealand's pastoral industries rely on pasture as a cheap high quality feed source to maintain a competitive advantage. White clover is a key component of this pastoral system. It constitutes $20-60 \%$ of pasture composition in intensive dairying systems in the Waikato, contributing on average $210 \mathrm{~kg} \mathrm{~N} / \mathrm{ha} /$ year (Ledgard et al. 1996). The national annual value of the nitrogen fixed by white clover is estimated at $\$ 1.49$ billion (1.57 million tonnes) (Caradus et al. 1995). White clover is valued in pastures for its high nutritive and feeding value (Ulyatt 1981). The higher animal weight gains (Ulyatt et al. 1977) and milk production (Thomson et al. 1977) of dairy cows feed a predominantly white clover diet compared with those fed perennial ryegrass (Lolium perenne) are explained by higher voluntary intakes and digestive efficiency by the animals. Clark \& Harris (1995) calculated that when the clover content was reduced from $20 \%$ to $10 \%$ the relative pasture yield must increase 1.15 times to give the equivalent gross margin on a Waikato dairy farm. White clover has a seasonal growth pattern complementary with that of ryegrass. The growth occurs later in the summer and autumn than for most pasture grasses (Harris 1987).

In New Zealand there would appear to be no climatic or cultural barriers to the spread of this pest. Populations of $S$. lepidus in Waikato pastures have been recorded at $1400 / \mathrm{m}^{2}$, equating to 50-60 per clover plant (Willoughby $\&$ Addison unpublished). Higher soil temperatures may favour more rapid development of the insect and natural predators and diseases have not yet been identified as a natural population checks. These factors and the key role that white clover plays in the profitability of pastoral farming in New Zealand indicate that S. lepidus has the potential to become a very serious problem for New Zealand farmers.

\section{Population study}

\section{Method}

Fifty soil cores, $75 \mathrm{~mm}$ diameter by 70 to $90 \mathrm{~mm}$ deep, were taken at varying intervals from January 1996 to
April 1997 from a dairy pasture near Hamilton. The cores were bulked together in a single plastic bag. Adult weevils, larvae and pupae were recovered from the soil cores by wet sieving and flotation in $\mathrm{MgSO}$ solution (Barker \& Addison 1989). Larvae recovered werre stored in $70 \%$ ethanol for later identification and head capsule width measurement.

At various intervals over the sampling period adult weevils were collected from the pasture using a motorised suction sampler. Following storage at $-20^{\circ} \mathrm{C}$ the weevils were dissected under a binocular microscope and their reproductive development visually scored on a $0-5$ scale $(0=$ no reproductive development since emergence; $5=$ ovarioles or testes fully developed). The presence or absence of eggs in the calyces of female weevils was also recorded.

\section{Results}

S. lepidus adults were first recovered from the pasture on 1 December 1995. Soil coring indicated adult numbers reached a peak of $14 / \mathrm{m}^{2}$ in March 1996 (Figure 1). These weevils became reproductive (Table 1) and numbers declined over winter. While the sample size was small, all those weevils collected over winter were active and fully reproductive. No weevils appeared to over-winter in a diapausing state. New adults began to emerge in October, numbers peaking around $70 / \mathrm{m}^{2}$ at the end of December before declining in January 1997. Weevil mean reproductive score increased steadily from October 1996 to late January 1997 when almost all weevils were sexually mature (Table 1 ). Adult emergence peaked at $135 / \mathrm{m}^{2}$ in late February before declining through March and April. These weevils were reproductive, most females having eggs in their calyces (Table 1).

Table 1 Reproductive status of clover root weevil adults in a Waikato dairy pasture.

\begin{tabular}{lccc}
\hline Date & $\begin{array}{c}\text { No. Weevils } \\
\text { dissected }\end{array}$ & $\begin{array}{c}\text { \% of females with } \\
\text { eggs in calyx }\end{array}$ & $\begin{array}{c}\text { Mean reproductive } \\
\text { score } \pm \text { SE }\end{array}$ \\
\hline 18.03 .96 & 19 & 100 & $4.90 \pm 0.39$ \\
24.04 .96 & 17 & 86 & $4.71 \pm 0.42$ \\
3.07 .96 & 6 & 100 & $5.00 \pm 0.00$ \\
9.08 .96 & 3 & 100 & $5.00 \pm 0.00$ \\
15.09 .96 & 2 & 100 & $5.00 \pm 0.00$ \\
12.10 .96 & 11 & 0 & $1.64 \pm 0.36$ \\
30.10 .96 & 37 & 44 & $2.65 \pm 0.31$ \\
14.11 .96 & 28 & 21 & $2.96 \pm 0.31$ \\
12.12 .96 & 40 & 47 & $3.48 \pm 0.26$ \\
23.12 .96 & 50 & 27 & $3.96 \pm 0.21$ \\
9.1 .97 & 30 & 47 & $4.00 \pm 0.30$ \\
21.1 .97 & 43 & 97 & $4.88 \pm 0.09$ \\
7.2 .97 & 50 & 68 & $4.14 \pm 0.22$ \\
22.2 .97 & 50 & 60 & $4.10 \pm 0.19$ \\
18.3 .97 & 50 & 39 & $3.96 \pm 0.22$ \\
24.4 .97 & 48 & 79 & $4.23 \pm 0.18$ \\
\hline
\end{tabular}


Figure 1 Sitona lepidus larval ( $3^{\text {rd }}$ to $5^{\text {th }}$ instars only), pupal and adult populations over 16 months following establishment in a Waikato pasture.

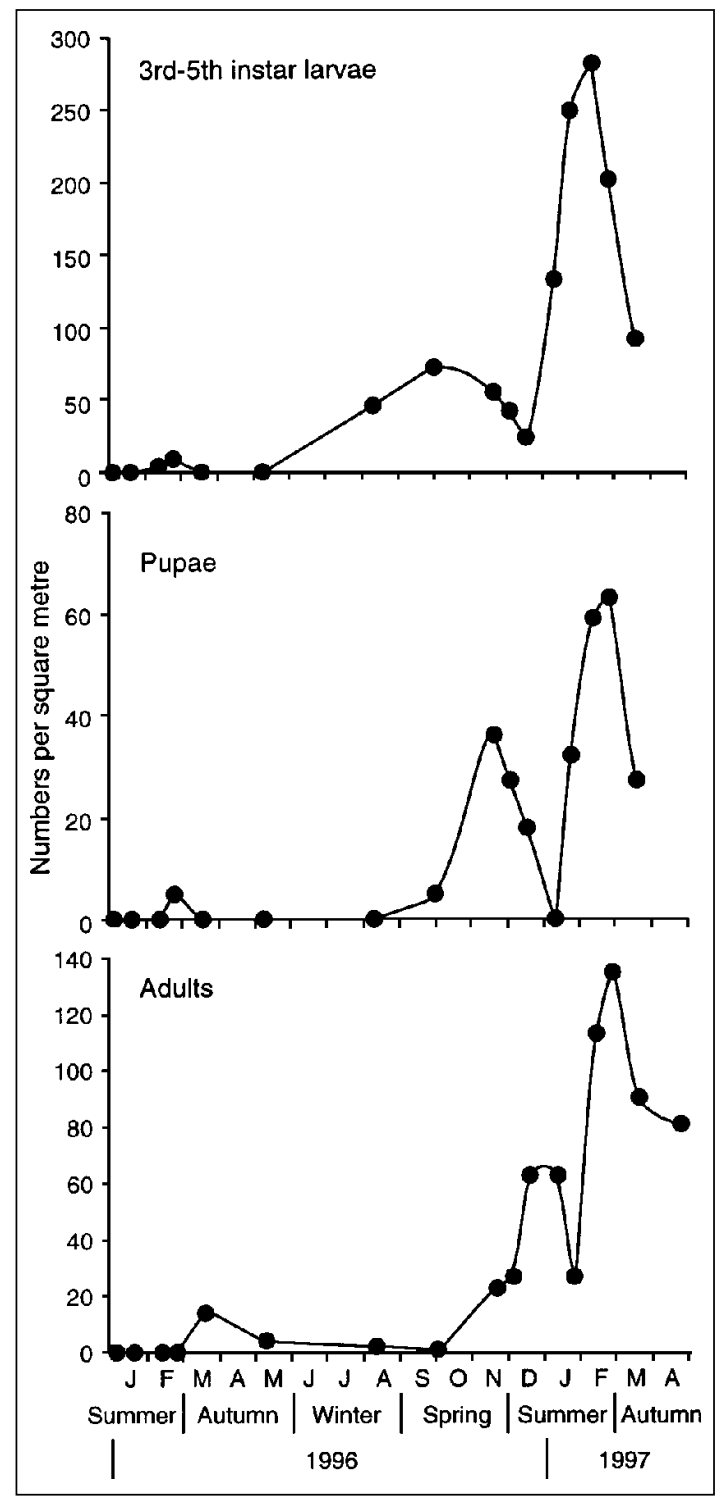

The recovery technique probably underestimated actual numbers of larvae present in the soil. The small size of the early instar larvae and the fact that many 1 st instar larvae burrow into root nodules could mean a significant proportion of small larvae were not recovered from the soil cores. Consequently, only the data for larger larvae (head capsule width $\geq 0.42 \mathrm{~mm}=3 \mathrm{rd}$ to 5th instar (Müller 1963)) are presented (Figure 1). Larvae were first recovered from the soil cores in February $1996\left(9 / \mathrm{m}^{2}\right)$. Larger larvae were not present in the soil cores in May, but numbers rose through August to peak at $72 / \mathrm{m}^{2}$ in late September. Numbers declined to $23 / \mathrm{m}^{2}$ in mid December then rose to $280 / \mathrm{m}^{2}$ in mid February 1997 before declining.

Pupae were first recorded in the soil cores in late February 1996. No pupae were found in the two winter samples. Pupal numbers began to rise in late September and peaked at $36 / \mathrm{m}^{2}$ in mid November before declining to zero in early January. A second peak $\left(63 / \mathrm{m}^{2}\right)$ of pupae occurred in late February 1997 (Figure 1).

\section{Discussion}

In Europe S. Lepidus appears to be mainly univoltine and over-winters as an adult (Murray pers. comm.; Markkula 1959). Over-wintered females begin egg laying in mid to late April in Romania (Brudea 1979) and mid May in Finland (Markkula 1959). In the UK peak egg numbers were recorded in September and October, although there is also an oviposition period in May and June (Mowat \& Clawson 1996). Larvae are present mostly from late spring through summer. In England, Murray \& Clements (1995) found late instar larval numbers to be high in June, declining through July and August and absent in September, while pupae were found in July and August. Adult emergence occurs mainly in late summer-autumn in Europe. Female weevils do not lay eggs before over-wintering in Finland (Markkula 1959).

By contrast female weevils emerging in late summer-autumn in the Waikato became reproductive and oviposited. The resultant larvae developed through the winter. The twin peaks of adult and larval numbers may reflect two generations. The absence of pupae in January 1997 lends credence to this theory. However, there more likely exists two asynchronous cohorts reflecting the delayed development of eggs laid later in the autumn of 1996. Further sampling through 1997 will eliminate one of these theories. Adult emergence in late spring/early summer was typical for pastures around the Waikato region (Addison \& Willoughby unpublished). Clover root weevil populations monitored at Waikato sites, including the Hamilton site, were much higher than those reported from pastures in England. Murray \& Clements (1995) surveyed 16 widespread sites in England and divided them into 3 groups depending on the agricultural area in grassland. Mean clover root weevil adult populations were typically less that 20/m² in 1993 and 1994 , while mean Sitona (S. lepidus and S. hispidulus) larval populations ranged from 34 to $90 / \mathrm{m}^{2}$ in June 1994 . White clover levels in the pastures were also typically low by New Zealand standards and probably regulated Sitona 
populations (Murray pers. comm.). Müller (1963) concluded regulation mechanisms existed for Sitona populations in the Leipzig area of Germany. He postulated that the major force which regulated population densities was competition for food amongst larvae.

New Zealand, with its temperate climate and high clover content in pastures, may be a very favourable environment for S. lepidus. The presence of both the larvae and adults throughout the year means that white clover has no respite from both foliar feeding and root pruning. The chronic stress effects this imposes on the plant is as yet unknown. In combination with other pests and diseases and climatic stresses, white clover growth and persistence may be greatly reduced. If so, this will have serious implications for New Zealand's pastoral farming, which is based on white clover for nitrogen fixation and nutritional quality.

\section{REFERENCES}

Barker, G.M.; Addison, P.J. 1989. Sampling Argentine stem weevil (Listronotus bonariensis) populations in pasture: The soil-dwelling stages. New Zealand journal of agricultural research 32: 95-103.

Barker, G.M.; Addison P.J.; Firth A.C.; Barratt, B.I.P. 1996. Sitona lepidus Gyllenhal newly established in New Zealand: Assessment of distribution in the North Island. Proceedings of the Forty Ninth New Zealand Plant Protection Conference: 266-269.

Barratt, B.I.P.; Barker, G.M.; Addison, P.J. 1996. Sitona lepidus Gyllenhal (Coleoptera: Curculionidae), a potential clover pest new to New Zealand. New Zealand entomologist 19: 23-30.

Bright, D.E. 1994 Revision of the genus Sitona (Coleoptera: Curculionidae) of North America. Annals of the Entomological Society of America 87: 277-306.

Brudea, V. 1979. Observations on the oviposition of the clover weevil Sitona flavescens Marsh. in the conditions of northern Moldavia. Probleme de protectia plantelor 7: 77-85.

Caradus, J.R.; Woodfield, D.R.; Stewart, A.V. 1995. Overview and vision for white clover. Agronomy Society of New Zealand Special Publication no. 11/ Grassland Research and Practice Series No. 6: 16.

Clark, D.A.; Harris, S.L. 1995. White clover or nitrogen fertiliser for dairying. Agronomy Society of New Zealand Special Publication no. 11/Grassland Research and Practice Series No. 6: 107-114.

Clements, R.O.; Murray, P.J. 1991. Incidence and severity of pest damage to white clover. Aspects of applied biology 27: 369-371.
Clements, R.O.; Murray, P.J. 1993. Sitona and other pest and disease damage to clover in the UK. FAO/ REUR Technical Series 29, White clover in Europe: State of the art: 149-150.

Culick, M.P.; Weaver, J.E., 1994. Seasonal crawling activity of adult root-feeding insect pests (Coleoptera: Curculionidae: Scolytidae) of red clover. Environmental entomology 23: 68-75

Esson, M.J. 1975. Notes on the biology and distribution of three recently discovered exotic weevil pests in the Hawke's Bay. Proceeding of the 28th New Zealand Weed and Pest Control Conference: 208212.

Forbes, T.J.; Dibb, C.; Green, J.O.; Hopkins, A.; Peel S. 1980. Factors affecting the productivity of permanent grassland. Hurley, UK: Joint GRI/ADAS Permanent Pasture Group.

Harris, W. 1987. Population dynamics and competition. pp. 203-297. In White clover. Baker, M.J.; Williams, W.M. (eds). Wallingford, UK: CAB International.

Hopkins, A.; Matkin, E.A.; Ellis, J.A.; Peel, S. 1985. Southwest England grassland survey 1983: 1. Age structure and sward composition of permanent and arable grassland and their relation to manageability, fertiliser nitrogen and other management features. Grass and Forage science 40: 349-359.

Hopkins, A. Wainwright, J., Murray, P.J., Bowling P.J. \& Webb, M. 1988. 1986 Survey of upland grassland in England and Wales: changes in age structure and botanical composition since 1970-72 in relation to grassland management and physical features. Grass and forage science 43: 185-189.

Ledgard, S.F. et al. 1996. Nitrogen losses from grazed dairy pasture, as affected by nitrogen fertiliser. Proceedings of the New Zealand Grassland Association 57: 21-25

Markkula, M. 1959. The biology and especially the oviposition of the Sitona Germ. species occurring as pests of leguminous plants in Finland. Valt. maatalousk. julk. 178: 41-74.

Markkula, M.; Koppa, P. 1960. The composition of the Sitona (Col., Curculionidae) population on grassland legumes and some other leguminous plants. Annales Entomologici Fennici 26: 246-264.

Mowat, D.J.; Shakeel M.A. 1988. The effect of pesticide application on the establishment of white clover in a newly-sown ryegrass-white clover sward. Grass and forage science 43: 371-375.

Mowat, D.J. \& Clawson S. 1996. Oviposition and hatching of the clover weevil Sitona lepidus Gyll. (Coleoptera: Curculionidae). Grass and forage science 51: 418-423

Müller, H. 1963. The dynamics of Sitona Germar (Curculionidae) populations in lucerne and red 
clover with reference to entomophagous parasites. Zool. jb. syst. bd. 90: 659-696.

Murray, P.J.; Clements R.O. 1992. A technique for assessing damage to roots of white clover caused by root feeding insects. Annals of applied biology 121: 715-719.

Murray, P.J.; Clements R.O. 1994. Investigations of the host feeding preferences of Sitona weevils commonly found on white clover (Trifolium repens) in the UK. Entomologia experimentalis et applicata 71: 7379.

Murray, P.J.; Clements R.O. 1995. Distribution and abundance of three species of Sitona weevils in grassland in England. Annals of applied biology 127: 229-237.

Murray, P.J.; Hatch D.J.; Cliquet, J.B. 1995. Effects of feeding by larvae of Sitona flavescens on white clover seedlings. Grassland into the 21st century: challenges and opportunities. Occasional Symposium No.29. British Grassland Society: 269-270.

Thomson, D.J. et al. 1985. Journal of dairy research 52: 17-31.

Ulyatt, J.J.; Lancashire, J.A.; Jones, W.T. 1977. The nutritive value of legumes. Proceedings of the New Zealand Grassland Association 38: 107-118

Wiech, K.; Clements, R.O. 1992. Studies on the Sitona spp. and Apion spp. weevils feeding on white clover foliage at a site in S.E. England. Journal of applied Enomology 133: 437-440.

Willoughby, B.; Addison, P. 1997. Assessment of the dispersal of Sitona lepidus (clover root weevil) in the North Island of New Zealand. Proceedings of the Fiftieth New Zealand Plant Protection Conference: 33-36. 
